\title{
Analisis fisik serta sensori kue kering dengan campuran tepung mocaf, oats, dan bekatul
}

Cookies' physical and sensory analysis with mixture of mocaf-oats-rice bran's flour

\author{
Monika Rahardjo $^{1)^{*}}$, Kristiawan Prasetyo Agung Nugroho ${ }^{2)}$, Greis Saibele ${ }^{2)}$ \\ ${ }^{1}$ Program Studi Teknologi Pangan, Fakultas Kedokteran dan Ilmu Kesehatan, \\ Universitas Kristen Satya Wacana \\ ${ }^{2}$ Program Studi Gizi, Fakultas Kedokteran dan Ilmu Kesehatan, Universitas Kristen Satya Wacana \\ *Email korespondensi : monika.rahardjo@uksw.edu
}

Informasi Artikel:

Dikirim: 03/12/2020; disetujui: 25/02/2021; diterbitkan: 15/09/2021

\begin{abstract}
This research aims to analyze the physical and sensory characteristics of cookies' formulations using mocaf-oats-rice bran's flour mixture. Five formulations used in this research consist of mocaf-oats-rice bran's flour mixture namely F1 (100\%-0\%-0\%), F2 (70\%-15\%-15\%), F3 (50\%-25\%-25\%), F4 (30\%-35\%-35\%), and F5 (0\%-50\%-50\%). The result showed that all cookies formulation included in the category of "high fiber" except for cookies Formulation 4. The highest value of hardness was cookies Formulation 1 and significantly different from the other formulations. Decreasing mocaf flour composition in the mixture and increasing additional oats and rice bran composition have a significant correlation on cookies' hardness. Based on sensory evaluation using rating preference, it was found that the highest rating for color, texture, and overall parameters obtained by cookies Formulation 4, while the highest rating for taste parameter obtained by cookies Formulation 5. Cookies' formulation that recommended to use as utilization of mocafflour was Formulation 4 because it had the highest rating for overall parameter, as well as highest rating for color and texture.
\end{abstract}

Keywords: Cookies, food innovation, mocaf, physical characteristics, sensory

\begin{abstract}
ABSTRAK
Penelitian ini bertujuan untuk menganalisis karakteristik fisikokimia serta sensori dari formulasi kue kering menggunakan campuran tepung mocaf, oats, dan bekatul. Lima formulasi campuran tepung mocaf-oats-bekatul yang digunakan dalam penelitian ini yaitu F1 (100\%-0\%-0\%), F2 (70\%-15\%-15\%), F3 (50\%-25\%-25\%), F4 (30\%-35\%$35 \%)$, dan F5 (0\%-50\%-50\%). Hasil menunjukkan bahwa semua formulasi kue kering termasuk kategori "tinggi serat" kecuali kue kering Formulasi 4. Nilai tingkat kekerasan paling tinggi adalah pada kue kering Formulasi 1 dan berbeda signifikan dari formulasi lainnya. Penurunan komposisi tepung mocaf dan peningkatan tambahan tepung oats dan bekatul berkorelasi signifikan pada tingkat kekerasan kue kering. Berdasarkan uji sensori rating kesukaan diperoleh bahwa rating tertinggi untuk parameter warna, tekstur, dan keseluruhan diperoleh kue kering Formulasi 4, sedangkan rating tertinggi untuk parameter rasa diperoleh kue kering Formulasi 5. Formulasi kue kering yang direkomendasikan untuk pemanfaatan tepung mocaf adalah Formulasi 4 karena memperoleh rating kesukaan keseluruhan tertinggi, sekaligus rating tertinggi untuk parameter warna dan tekstur.
\end{abstract}

Kata kunci: inovasi pangan, karakteristik fisik, kue kering, mocaf, sensori 


\section{PENDAHULUAN}

Umbi-umbian merupakan salah satu komoditas yang melimpah di Indonesia, salah satunya adalah ubi kayu. Berdasarkan data tahun 2011 sampai tahun 2015, produktivitas ubi kayu Indonesia mengalami peningkatan, pada tahun 2015 saja produktivitas ubi kayu di Indonesia mencapai kurang lebih 23,58 ton per ha, meningkat dari tahun sebelumnya yaitu 23,34 ton per ha (Kementerian Pertanian, 2015). Saat ini, ubi kayu ini telah banyak diteliti dan dikembangkan pengolahannya sebagai tepung ubi kayu termodifikasi (modified cassava flour) atau dikenal dengan sebutan mocaf.

Tepung mocaf mempunyai karakteristik kandungan gizi yang mirip dengan tepung terigu, namun kandungan protein, serat, vitamin dan mineralnya rendah (Wondrak et al., 2010) sehingga dalam proses pengolahannya perlu ditambahkan sumber-sumber gizi makro dan mikro. Walaupun pengembangan tepung mocaf telah banyak dilakukan, namun pemanfaatannya untuk pengolahan produk pangan masih bisa banyak dieksplorasi, terutama untuk produk bakery.

Oats dan tepung bekatul telah banyak disebutkan sebagai sumber serat pangan yang bermanfaat untuk kesehatan (Cara et al., 1992; Wang et al., 2016). Serat pangan sendiri telah direkomendasikan secara umum untuk dikonsumsi harian minimal sebesar 28 $\mathrm{g}$ per hari untuk wanita dewasa dengan energi $2000 \mathrm{kcal}$ per hari dan sebesar $36 \mathrm{~g}$ per hari untuk pria dewasa dengan energi 2600 kcal per hari (Ötles \& Ozgoz, 2014). Pengaplikasian sumber serat seperti oats dan bekatul dalam produk olahan pangan dapat membantu meningkatkan rata-rata asupan serat yang umumnya masih kurang di Indonesia (Ambarita et al., 2014). Kue kering merupakan salah satu produk olahan pangan yang siap makan (ready to eat) dan disukai oleh masyarakat hampir semua usia. Oleh karena itu, tujuan penelitian ini adalah untuk menganalisis karakteristik fisik dan sensori kue kering dengan campuran tepung mocaf, oats, dan bekatul.

\section{METODE}

\section{Bahan}

Bahan pembuatan kue kering yang digunakan dalam penelitian ini adalah tepung mocaf, oats, serta bekatul. Tepung mocaf dibeli dari Argo Nirmala Sejahtera, oats dibeli dari PT Kobe Boga Utama, dan bekatul dibeli dari CV Langkah Baru Sukses. Bahan analisis kimia yang digunakan meliputi n-heksana (Merck; 99,9\%), $\mathrm{H}_{2} \mathrm{SO}_{4}$ (Merck; 99,9\%), $\mathrm{NaOH}$ (Merck; 99,9\%).

Alat

Peralatan yang digunakan untuk pembuatan cookies meliputi mixer (Philips HR1552) dan oven (Bima Jaya). Peralatan analisis yang digunakan meliputi Chromameter (Konika Minolta CR400), Texture Analyzer (Lloyd TA Plus), Spektrofotometer (UV-1280 Shimadzu), IWAKI Soxh-Set-1000, moisture balance (Pioneer MB25), Kjedahl (VELP Scientifica UDK 139).

\section{Metode dan analisis}

Komposisi bahan serta metode pembuatan kue kering merujuk pada Suas (2009). Rancangan penelitian dapat dilihat pada Tabel 1.

Tabel 1. Rancangan penelitian campuran tepung untuk pembuatan kue kering

\begin{tabular}{lccccc}
\hline \multirow{2}{*}{ Jenis Tepung } & \multicolumn{5}{c}{ Formulasi $(\%)$} \\
\cline { 2 - 6 } & 1 & 2 & 3 & 4 & 5 \\
\hline Tepung Mocaf & 100 & 70 & 50 & 30 & 0 \\
Tepung Oats & 0 & 15 & 25 & 35 & 50 \\
Tepung Bekatul & 0 & 15 & 25 & 35 & 50 \\
\hline TOTAL & 100 & 100 & 100 & 100 & 100 \\
\hline
\end{tabular}


Komposisi formulasi disesuaikan dengan rancangan penelitian. Analisis yang dilakukan meliputi analisis warna, analisis fisik, analisis sensori, analisis kimia, serta analisis statistik.

Analisis warna dilakukan menggunakan Chromameter (Konika Minolta CR400) sesuai dengan prosedur yang dilakukan oleh Altindag et al. (2015). Hasil analisis yang dihasilkan berupa nilai $\mathrm{L}^{*}$ (tingkat kecerahan), a* (tingkat warna merah ke hijau, nilai positif ke negatif secara berturut-turut), dan $b^{*}$ (tingkat warna kuning ke biru, nilai positif ke negatif berturutturut). Analisis fisik yang dilakukan menggunakan Texture Analyzer (Lloyd TA Plus) sesuai dengan prosedur yang dilakukan oleh Kulthe et al. (2014) di mana hasil analisis yang dihasilkan adalah hardness $(g f)$ dan work (kgf.mm).

Analisis sensori dilakukan dengan menggunakan uji penerimaan rating kesukaan (Meilgaard et al., 2015) dari empat parameter yaitu warna, rasa, tekstur, dan penerimaan secara keseluruhan. Rating yang digunakan adalah rating dengan 5 skala (skala 1 merupakan skala yang paling tidak disukai sampai skala 5 merupakan skala yang paling disukai). Panelis yang digunakan untuk uji sensori sebanyak 40 panelis tidak terlatih. Analisis kimia untuk kue kering dilakukan untuk mengetahui komposisi proksimat dari kue kering. Analisis proksimat menggunakan metode dari AOAC (2002) sedangkan untuk kandungan serat (\%) menggunakan metode dari American Association of Cereal Chemists (2000).

Data yang diperoleh dianalisis menggunakan analysis of variance (ANOVA) pada $\alpha=5 \%$ untuk mengetahui adanya pengaruh nyata pada setiap parameter pengujian. Hasil yang signifikan dari perhitungan ANOVA kemudian dilanjutkan dengan Duncan's Multiple Range Test pada $\alpha=5 \%$ untuk menentukan taraf perlakuan yang memberikan perbedaan nyata. Uji korelasi antara peningkatan dan penurunan komposisi tepung mocaf, oats, dan bekatul pada tingkat kekerasan diuji statistik menggunakan uji Pearson. Keseluruhan pengujian statistik dibantu dengan menggunakan software IBM SPSS Statistics 20 .

\section{HASIL DAN PEMBAHASAN}

\section{Karakteristik kimia}

Hasil uji proksimat kue kering berbagai formulasi dapat dilihat pada Tabel 2.

Tabel 2. Hasil uji proksimat cookies berbagai formulasi

\begin{tabular}{lccccc}
\hline Parameter & Formulasi 1 & Formulasi 2 & Formulasi 3 & Formulasi 4 & Formulasi 5 \\
\hline Kadar Air(\%) & $3,87 \pm 0,23$ & $12,5 \pm 0,38$ & $8,74 \pm 0,11$ & $9,71 \pm 0,10$ & $3,88 \pm 0,24$ \\
Kadar Protein(\%) & $6,67 \pm 0,16$ & $4,17 \pm 0,16$ & $4,9 \pm 0,16$ & $3,51 \pm 0,26$ & $4,38 \pm 0,19$ \\
Kadar Karbohidrat(\%w/w) & $36,25 \pm 0,50$ & $28,39 \pm 0,71$ & $30,78 \pm 0,32$ & $32,17 \pm 0,53$ & $30,61 \pm 0,42$ \\
Kadar Lemak(\%) & $31,14 \pm 0,42$ & $29,55 \pm 0,25$ & $31,65 \pm 0,51$ & $26,51 \pm 0,27$ & $29,86 \pm 0,15$ \\
Kadar Serat(\%) & $23,28 \pm 0,17$ & $6,76 \pm 0,18$ & $11,71 \pm 0,24$ & $2,57 \pm 0,13$ & $8,92 \pm 0,11$ \\
\hline
\end{tabular}

Perhitungan ANOVA menghasilkan bahwa hasil proksimat kue kering tidak berbeda signifikan antara semua formula. Dilihat dari sisi gizinya, produk makanan diklaim sebagai "sumber serat" apabila mengandung minimal $3 \mathrm{~g}$ per $100 \mathrm{~g}$ serat dan dikatakan "tinggi serat" apabila mengandung minimal $6 \mathrm{~g}$ per $100 \mathrm{~g}$ serat dalam komposisinya (Ng et al., 2017; European Commision, 2006). Hasil penelitian ini menunjukkan bahwa mayoritas kue kering dapat dikategorikan sebagai kue kering yang "tinggi serat" kecuali kue kering Formulasi 4. Hal ini disebabkan karena dalam formulasi adonan kue kering ditambahkan tepung oats dan bekatul yang merupakan sumber serat. Semakin tinggi kandungan serat pada produk pangan semakin baik fungsinya untuk kesehatan terutama untuk pencernaan dan mencegah penyakit kardiovaskular (McRae, 2017; Threapleton et al., 2013). 
Secara umum, kue kering dikategorikan sebagai produk yang rendah kandungan airnya, rata-rata berkisar 1-5\% (Giuberti et al., 2018). Kue kering yang dihasilkan dalam penelitian ini mempunyai kandungan air yang bervariasi, di mana kue kering Formulasi 1 dan Formulasi 4 sesuai dengan kategori rendah kandungan airnya. Fungsi kandungan air yang rendah adalah meminimalkan potensi kerusakan oleh mikroba sehingga umur simpannya lebih lama (Ng et al., 2017).

Pada proses pembuatan kue kering, gula ditambahkan untuk menambah rasa manis sehingga meningkatkan palatabilitasnya. Selain itu, gula juga biasanya ditambahkan dalam proses pengolahan produk pangan sebagai bahan pengawet alami serta meningkatkan sifatsifat fungsionalnya seperti viskositas, tekstur, dan kapasitas browning (Slavin dan Carlson 2014). Keberadaan karbohidrat dan air dalam adonan produk bakery berperan pada tekstur dan struktur fisik pada saat proses baking, disebabkan oleh bergabungnya granula pati dengan air menjadi gel (Okorie dan Onyeneke, 2012).

Lemak merupakan salah satu sumber gizi makro. Pedoman untuk kandungan lemak total produk pangan yang direkomendasikan oleh $\mathrm{FAO} / \mathrm{WHO}$ adalah dalam rentang 20-35\% (FAO, 2010). Dilihat pada Tabel 2, semua formulasi kue kering dalam penelitian ini masih termasuk dalam rentang kandungan lemak total yang direkomendasikan FAO/WHO. Dalam proses pembuatan kue kering, lemak berperan pada plastisitas kue kering sehingga berpengaruh pada tekstur kue kering (Devi dan Khatkar 2016).

\section{Karakteristik fisik}

Tabel 3 menunjukkan salah satu parameter fisik dari kue kering yaitu tekstur (hardness dan work).

Tabel 3. Hasil pengujian fisik berbagai formulasi

\begin{tabular}{lccccc}
\hline & & $\begin{array}{c}\text { Work } \\
\text { Hardness }(\mathrm{gf})\end{array}$ & $\mathrm{L}^{*}$ & $\mathrm{a}^{*}$ & $\mathrm{~b}^{*}$ \\
\hline Formulasi 1 & $1965,52 \pm 258,25^{2}$ & $2,19 \pm 0,56^{2}$ & $72,16 \pm 0,02^{1}$ & $1,57 \pm 0,01^{1}$ & $26,73 \pm 0,03^{1}$ \\
Formulasi 2 & $578,89 \pm 30,07^{1}$ & $0,71 \pm 0,13^{1}$ & $71,99 \pm 0,01^{1}$ & $2,45 \pm 0,01^{1}$ & $21,75 \pm 0,02^{1}$ \\
Formulasi 3 & $810,50 \pm 58,64^{1}$ & $1,08 \pm 0,45^{1}$ & $72,89 \pm 0,03^{1}$ & $2,29 \pm 0,01^{1}$ & $24,99 \pm 0,02^{1}$ \\
Formulasi 4 $^{1}$ & $732,57 \pm 50,34^{1}$ & $1,04 \pm 0,13^{1}$ & $72,72 \pm 0,02^{1}$ & $2,44 \pm 0,01^{1}$ & $12,96 \pm 0,01^{1}$ \\
Formulasi 5 & $718,67 \pm 3,36^{1}$ & $1,36 \pm 0,85^{1,2}$ & $61,68 \pm 0,01^{1}$ & $3,87 \pm 0,02^{1}$ & $20,48 \pm 0,02^{1}$ \\
\hline
\end{tabular}

Keterangan: Angka superscript yang berbeda pada kolom yang sama menunjukkan perbedaan yang signifikan $(p>0,05)$

Hardness menunjukkan tingkat kekerasan dari kue kering sedangkan work menunjukkan besar usaha untuk mengunyahnya. Dari uji ANOVA, tingkat kekerasan pada Formulasi 1 berbeda signifikan dengan formulasi lainnya. Berdasarkan uji korelasi, tingkat kekerasan pada kue kering berkorelasi positif dengan besar usaha mengunyah, di mana semakin tinggi nilai tingkat kekerasan maka besar usaha mengunyahnya juga akan semakin tinggi. Tingkat kekerasan pada kue kering berhubungan dengan interaksi campuran air, pati, dan protein dalam komposisi tepung yang digunakan dalam proses pembuatan kue kering. Semakin tinggi nilai tingkat kekerasan berkorelasi dengan semakin tinggi kandungan protein yang berperan dalam pembentukan struktur yang semakin keras sebagai hasil dari kuatnya interaksi antara protein dan pati karena ikatan hidrogen (Wani et al., 2012).

Pada penelitian ini, nilai tingkat kekerasan yang paling tinggi adalah kue kering Formulasi 1. Hasilnya sesuai dengan penelitian yang dilakukan oleh Wani et al. (2012) di mana kandungan protein berkorelasi dengan tingkat kekerasan, semakin tinggi kandungan protein menyebabkan nilai tingkat kekerasannya juga semakin tinggi. Tampak dari hasil penelitian ini, kandungan protein yang paling tinggi kue kering Formulasi 1 
menyebabkan nilai tingkat kekerasan yang paling tinggi juga dibandingkan dengan formulasi lainnya. Selain itu, kandungan serat juga berperan pada tingkat kepadatan adonan (Ostermann-Porcel et al., 2017; Zouari et al., 2016) dan hasil yang diperoleh dalam penelitian ini juga sesuai, kandungan serat pada kue kering Formulasi 1 yang paling tinggi berkorelasi pada nilai tingkat kekerasan yang tinggi juga.

Secara keseluruhan pada Tabel 2 dapat dilihat bahwa dengan menurunnya komposisi tepung mocaf yang digunakan dan meningkatnya komposisi oats dan bekatul yang digunakan akan menurunkan nilai tangkat kekerasan, kecuali pada kue kering Formulasi 2. Pengujian statistik dengan uji Pearson membuktikan bahwa penurunan komposisi tepung mocaf dan peningkatan penambahan oats dan bekatul berkorelasi signifikan pada nilai tingkat kekerasan kue kering. Hal ini disebabkan karena dengan penambahan oats serta bekatul yang mengandung serat dalam adonan kue kering meningkatkan elastisitas kue kering sehingga menyebabkan teksturnya menjadi lebih empuk (Kurek et al., 2016).

Hasil uji kromameter kue kering berbagai variasi dapat dilihat pada Tabel 3 . Secara perhitungan ANOVA tidak ada perbedaan signifikan yang dihasilkan pada semua formulasi baik dari tingkat kecerahan $\left(\mathrm{L}^{*}\right)$, rona merah $\left(\mathrm{a}^{*}\right)$, maupun rona kuning $\left(b^{*}\right)$. Semakin tinggi komposisi tepung oats dan bekatul dalam campuran tepung formulasi kue kering memperlihatkan semakin tingginya tingkat rona merah $\left(\mathrm{a}^{*}\right)$, kecuali pada Formulasi 3. Warna dari kue kering sendiri berhubungan tidak hanya dengan warna tepung yang digunakan, namun dengan reaksi Maillard yang terjadi saat proses baking. Reaksi Maillard sendiri merupakan reaksi yang terjadi antara protein atau asam amino dengan gula pereduksi, di mana hasil reaksinya akan berkontribusi pada profil flavor dari produk pangan (Demyttenaere et al., 2009). Ronamerah (dilihat dari $a^{*}$ yang nilainya positif) mengindikasikan terjadi proses nonenzymatic browning dari hasil berlangsungnya reaksi Maillard. Berdasarkan penelitian sebelumnya oleh Mancebo et al. (2015), kandungan protein tidak berkorelasi dengan tingkat kecerahan $\left(\mathrm{L}^{*}\right)$ kue kering.

\section{Karakteristik sensori rating penerimaan kue kering}

Kue kering dengan lima formulasi juga diujikan sensori menggunakan uji penerimaan rating kesukaan 5 skala (skala 1 merupakan yang paling tidak disukai sampai dengan skala 5 merupakan yang paling disukai) dengan 40 panelis tidak terlatih, hasilnya dapat dilihat pada Tabel 4. Parameter yang digunakan adalah warna, rasa, tekstur, serta kesukaan secara keseluruhan. Perhitungan ANOVA terhadap data dari uji sensori menunjukkan bahwa semua parameter mempunyai perbedaan yang signifikan $(\alpha=5 \%)$ antar formulasi kecuali untuk parameter warna.

Parameter rasa pada uji rating kesukaan menunjukkan rating kesukaan rasa yang tertinggi diperoleh kue kering Formulasi 5, namun tidak berbeda signifikan dengan Formulasi 3 dan 4. Untuk produk bakery, salah satu rasa yang muncul adalah akibat reaksi karamelisasi dari kandungan gula di dalamnya. Selain berpengaruh terhadap rasa, karamel juga merupakan sumber antioksidan, tergantung pada $\mathrm{pH}$ dan jenis gula (Sengar dan Sharma 2014).

Tekstur merupakan salah satu parameter terpenting yang berhubungan dengan kualitas produk. Tabel 4 menunjukkan bahwa rating kesukaan tekstur tertinggi diperoleh kue kering Formulasi 4, namun tidak berbeda signifikan dengan Formulasi 3 dan 5, sama apabila dibandingkan dengan hasil nilai tingkat kekerasan pada Tabel 3. Nilai tingkat kekerasan berkorelasi dengan seberapa usaha yang dibutuhkan panelis untuk menggigit dan mengunyah (work). Panelis cenderung memilih kue kering nilai tingkat kekerasanyang tidak terlalu tinggi seperti pada kue kering Formulasi 1. Selain itu, kandungan serat dalam kue kering juga mempengaruhi teksturnya karena menyebabkan tingkat kesusahan panelis untuk mengunyah dan menelan semakin tinggi (Duta dan Culetu, 2015). 
Tabel 4. Hasil uji sensori penerimaan rating kesukaan

\begin{tabular}{|c|c|c|c|c|}
\hline & Warna & Rasa & Tekstur & Overall \\
\hline Formulasi 1 & $2,28 \pm 1,04^{1,2}$ & $1,65 \pm 0,83^{1}$ & $1,78 \pm 0,66^{1}$ & $1,70 \pm 0,61^{1}$ \\
\hline Formulasi 2 & $2,53 \pm 0,88^{1,2}$ & $1,98 \pm 0,89^{1,2}$ & $2,10 \pm 0,98^{1,2}$ & $2,10 \pm 0,74^{2}$ \\
\hline Formulasi 3 & $2,50 \pm 0,85^{1,2}$ & $2,43 \pm 1,04^{2,3}$ & $2,38 \pm 0,87^{2,3}$ & $2,43 \pm 0,84^{2,3}$ \\
\hline Formulasi 4 & $2,70 \pm 0,76^{2}$ & $2,33 \pm 1,05^{2,3}$ & $2,63 \pm 1,01^{3}$ & $2,58 \pm 0,87^{3}$ \\
\hline Formulasi 5 & $2,20 \pm 1,20^{1}$ & $2,75 \pm 1,10^{3}$ & $2,55 \pm 1,06^{3}$ & $2,50 \pm 1,04^{3}$ \\
\hline
\end{tabular}

Keterangan: Angka superscript yang berbeda pada kolom yang sama menunjukkan perbedaan yang signifikan $(p>0,05)$

Warna yang atraktif akan meningkatkan tingkat kesukaan konsumen terhadap produk pangan. Kue kering Formulasi 4 mempunyai rating kesukaan warna paling tinggi, namun tidak berbeda nyata dengan Formulasi 1, 2, dan 3. Perbedaan signifikan yang terjadi pada kue kering Formulasi 5 dengan formulasi lainnya adalah karena pada Formulasi 5 tidak ditambahkan tepung mocaf dalam adonan. Apabila dibandingkan hasilnya dengan Tabel 3, dapat terlihat bahwa kue kering Formulasi 5 mempunyai tingkat kecerahan $\left(\mathrm{L}^{*}\right)$ paling rendah dan tingkat rona merah $\left(\mathrm{a}^{*}\right)$ paling tinggi dibandingkan kue kering formulasi lainnya.

Penerimaan secara keseluruhan merangkum tingkat kesukaan keseluruhan parameter, baik warna, rasa, dan tekstur dari kue kering. Secara keseluruhan, kue kering Formulasi 4 memperoleh rating kesukaan keseluruhan $l$ tertinggi dibandingkan formulasi yang lain, namun tidak berbeda signifikan dengan kue kering Formulasi 3 dan 5. Secara umum dapat dilihat pada Tabel 4 bahwa penambahan tepung oats dan bekatul pada adonan kue kering dengan tepung mocaf meningkatkan rating tingkat kesukaan panelis pada kue kering secara signifikan. Berdasarkan pengujian sensori maka direkomendasikan kue kering Formulasi 4 karena memperoleh rating kesukaan keseluruhan rating tertinggi, sekaligus rating tertinggi juga untuk parameter warna dan tekstur.

\section{KESIMPULAN}

Penurunan komposisi tepung mocaf dan peningkatan komposisi penambahan tepung oats dan bekatul berkorelasi signifikan padatingkat kekerasan kue kering.
Tingkat kekerasan paling tinggi ditemukan pada Formulasi 1 komposisi di mana tepung yang digunakan adalah $100 \%$ tepung mocaf. Mayoritas formulasi kue kering dalam penelitian ini termasuk kategori "tinggi serat" kecuali pada Formulasi 4. Berdasarkan uji sensori rating kesukaan, diperoleh bahwa rating tertinggi untuk parameter warna, tekstur, dan keseluruhan diperoleh pada kue kering Formulasi 4, sedangkan rating tertinggi untuk parameter rasa diperoleh kue kering Formulasi 5. Berdasarkan pengujian sensori maka direkomendasikan kue kering Formulasi 4 karena memperoleh rating kesukaan keseluruhan tertinggi, sekaligus rating tertinggi juga untuk parameter warna dan tekstur. Ke depannya perlu dilakukan penelitian lebih lanjut untuk meningkatkan rating kesukaan parameter kue kering dengan formulasi campuran tepung yang sama, terutama dengan komposisi Formulasi 4 dan 5 .

\section{DAFTAR PUSTAKA}

AACC (American Association of Cereal Chemists). (2000). Approved Methods of the American Association of Cereal Chemists. St. Paul: AACC.

Altindag, G., Certel, M., Erem, F., \& Ilknur Konak, Ü. (2015). Quality characteristics of gluten-free cookies made of buckwheat, corn, and rice flour with/without transglutaminase. Food Science and Technology International, 21(3), 213-220. https://doi.org/10.1177/1082013214525 428

Ambarita, E. M., Madanijah, S., \& Masyarakat, D. G. (2014). Hubungan Asupan Serat Makanan Dan Air Dengan 
Pola Defekasi Anak Sekolah Dasar Di Kota Bogor. Jurnal Gizi Dan Pangan, 9(1), 7-14. https://doi.org/10.25182/jgp.2014.9.1.

AOAC (Association of Official Analytical Chemists). (2002). Guidelines for single laboratory validation of chemical methods for dietary supplements and botanicals. AOAC International, 1-38.

Cara, L., Dubois, C., Borel, P., Armand, M., Senft, M., Portugal, H., ... Lairon, D. (1992). Effects of oat bran, rice bran, wheat fiber, and wheat germ on postprandial lipemia in healthy adults. The American Journal of Clinical Nutrition, $\quad 55(1), \quad 81-88$. https://doi.org/10.1093/ajcn/55.1.81

Demyttenaere, J., Tehrani, K. A., \& De Kimpe, N. (2009). The Chemistry of the Most Important Maillard Flavor Compounds of Bread and Cooked Rice, (Figure 1), 150-165. https://doi.org/10.1021/bk-20020826.ch009

Devi, A., \& Khatkar, B. S. (2016). Physicochemical, rheological and functional properties of fats and oils in relation to cookie quality: a review. Journal of Food Science and Technology, 53(10), 3633-3641. https://doi.org/10.1007/s13197-0162355-0

Duta, D. E., \& Culetu, A. (2015). Evaluation of rheological, physicochemical, thermal, mechanical and sensory properties of oat-based gluten free cookies. Journal of Food Engineering, 162 , 1-8. https://doi.org/10.1016/j.jfoodeng.2015. 04.002

Food and Agriculture Organization. (2010). Fats and fatty acids in human nutrition. Rome. Retrieved from http://www.fao.org/3/a-i1953e.pdf

Giuberti, G., Rocchetti, G., Sigolo, S., Fortunati, P., Lucini, L., \& Gallo, A. (2018). Exploitation of alfalfa seed (Medicago sativa L.) flour into glutenfree rice cookies: Nutritional, antioxidant and quality characteristics.
Food Chemistry, 239, 679-687. https://doi.org/10.1016/j.foodchem.201 7.07.004

Kulthe, A. A., Pawar, V. D., Kotecha, P. M., Chavan, U. D., \& Bansode, V. V. (2014). Development of High Protein and Low Calorie Cookies. Food Science and Technology, 51(1). https://doi.org/10.1007/s13197-0110465-2

Kurek, M., Wyrwisz, J., Piwińska, M., \& Wierzbicka, A. (2016). The Effect of Oat Fibre Powder Particle Size on the Physical Properties of Wheat Bread Rolls. Food Technology and Biotechnology, 54(1), 45-51. https://doi.org/10.17113/ftb.54.01.16.41 77

Mancebo, C. M., Picón, J., \& Gómez, M. (2015). Effect of flour properties on the quality characteristics of gluten free sugar-snap cookies. LWT - Food Science and Technology, 64(1), 264269.

https://doi.org/10.1016/j.lwt.2015.05.05 7

McRae, M. P. (2017). Dietary Fiber Is Beneficial for the Prevention of Cardiovascular Disease: An Umbrella Review of Meta-analyses. Journal of Chiropractic Medicine, 16(4), 289-299. https://doi.org/10.1016/j.jcm.2017.05.0 05

Meilgaard, M. C., Carr, B. T., \& Civille, G. V. (2007). Sensory Evaluation Techniques, Fifth Edition. CRC Press.

Ng, S. H., Robert, S. D., Wan Ahmad, W. A. N., \& Wan Ishak, W. R. (2017). Incorporation of dietary fibre-rich oyster mushroom (Pleurotus sajor-caju) powder improves postprandial glycaemic response by interfering with starch granule structure and starch digestibility of biscuit. Food Chemistry, 227 , 358-368. https://doi.org/10.1016/j.foodchem.201 7.01.108

Okorie, S. U., \& Onyeneke, E. . (2012). Production and Quality Evaluation of Baked Cake. Natural and Applied 
Sciences, 3(2), 171-177.

Ostermann-Porcel, M. V., Quiroga-Panelo, N., Rinaldoni, A. N., \& Campderrós, M. E. (2017). Incorporation of Okara into Gluten-Free Cookies with High Quality and Nutritional Value. Journal of Food Quality, 2017 , $1-8$. https://doi.org/10.1155/2017/4071585

Ötles, S., \& Ozgoz, S. (2014). Health effects of dietary fiber. Acta Scientiarum Polonorum, Technologia Alimentaria, 13(2), 191-202. https://doi.org/10.17306/J.AFS.2014.2.8

Kementerian Pertanian Republik Indonesia. (2015). Outlook Komoditas Pertanian Tanaman Pangan. Jakarta: Kemeterian Pertanian Republik Indonesia. Retrieved from http://epublikasi.setjen.pertanian.go.id/e publikasi/outlook/2015/Tanaman

Pangan/Outlook Ubikayu 2015/files/assets/common/downloads/O utlook Ubikayu 2015.pdf

Sengar, G., \& Sharma, H. K. (2014). Food caramels: a review. Journal of Food Science and Technology, 51(9), 16861696. https://doi.org/10.1007/s13197012-0633-z

Slavin, J., \& Carlson, J. (2014). Carbohydrates. Advances in Nutrition (Bethesda, Md.), 5(6), 760-761. https://doi.org/10.3945/an.114.006163

Suas, M. (2009). Advanced bread and pastry: a professional approach. Delmar Cengage Learning. Retrieved from https://books.google.co.id/books/about/ Advanced_Bread_and_Pastry.html?id=J M76vm5tH38C\&redir_esc $=y$

Threapleton, D. E., Greenwood, D. C., Evans, C. E. L., Cleghorn, C. L., Nykjaer, C., Woodhead, C., ... Burley, V. J. (2013). Dietary fibre intake and risk of cardiovascular disease: systematic review and meta-analysis. BMJ (Clinical Research Ed.), 347, f6879.

https://doi.org/10.1136/bmj.f6879
Wang, J., Suo, G., de Wit, M., Boom, R. M., \& Schutyser, M. A. I. (2016). Dietary fibre enrichment from defatted rice bran by dry fractionation. Journal of Food Engineering, 186, 50-57. https://doi.org/10.1016/j.jfoodeng.2016. 04.012

Wani, A. A., Sogi, D. S., Singh, P., Sharma, P., \& Pangal, A. (2012). DoughHandling and Cookie-Making Properties of Wheat Flour-Watermelon Protein Isolate Blends. Food and Bioprocess Technology, 5(5), 16121621. https://doi.org/10.1007/s11947010-0466-6

Wondrak, G., Villeneuve, N. F., Lamore, S. D., Bause, A. S., Jiang, T., \& Zhang, D. D. (2010). The Cinnamon-Derived Dietary Factor Cinnamic Aldehyde Activates the Nrf2-Dependent Antioxidant Response in Human Epithelial Colon Cells. Molecules, 15(5), 3338-3355. https://doi.org/10.3390/molecules15053 338

Zouari, R., Besbes, S., Ellouze-Chaabouni, S., \& Ghribi-Aydi, D. (2016). Cookies from composite wheat-sesame peels flours: Dough quality and effect of Bacillus subtilis SPB1 biosurfactant addition. Food Chemistry, 194, 758769.

https://doi.org/10.1016/j.foodchem.201 5.08 .064 